Research Report No. 20/2011

\title{
Towards Classical Legal Positivism
}

Dan Priel

Osgoode Hall Law School of York University, dpriel@osgoode.yorku.ca

Follow this and additional works at: http:/ / digitalcommons.osgoode.yorku.ca/clpe

\section{Recommended Citation}

Priel, Dan, "Towards Classical Legal Positivism" (2011). Comparative Research in Law \& Political Economy. Research Paper No. 20/2011. http://digitalcommons.osgoode.yorku.ca/clpe/58 


\section{OSGOODE}

OSGOODE HALL LAW SCHOOL

YOR K U N I VERSITY

\section{OSGOODE HALL LAW SCHOOL}

Comparative Research in Law \& Political Economy

RESEARCH PAPER SERIES

Research Paper No. 20/2011

\section{Towards Classical Legal Positivism}

Dan Priel

\section{Editors:}

Peer Zumbansen (Osgoode Hall Law School, Toronto, Director Comparative Research in Law and Political Economy)

John W. Cioffi (University of California at Riverside)

Leeanne Footman (Osgoode Hall Law School, Toronto, Production Editor)

Comparative Research in Law \& Political Economy 


\title{
Towards Classical Legal Positivism
}

\author{
Dan Priel
}

\begin{abstract}
Open almost any textbook or jurisprudence and you will find it beginning with a discussion of natural law and legal positivism. What sets them apart, we are told, is a difference on the conceptual question of the relationship between law and morality. Natural lawyers believe that law or legality are necessarily connected to morality, whereas legal positivists deny that. In this essay I challenge this fundamental understanding of the debate. The difference between legal positivism and natural law has to do with a way inquiries about law should be conducted: natural lawyers seek to understand law by relating it to a broader metaphysical picture or a picture of human nature; legal positivist begin their inquiry with observations at legal practice. Based on this finding I turn to the work of those philosophers nowadays often considered the founders of legal positivism, Thomas Hobbes and Jeremy Bentham. I show that unlike contemporary legal positivists they understood their enterprise in ways much closer to those of the natural lawyers, only that their metaphysical picture was profoundly differently from that of most their natural law contemporaries. This leads to several findings: that early legal positivists were very different from contemporary legal positivists (something that explains why their positivists credentials are questioned these days); that contemporary jurisprudential debate between legal positivists and natural lawyers involves, to a great extent, two groups talking past each other; and that contemporary legal positivism is a philosophically uninteresting enterprise. I conclude by suggesting that it is the metaphysical version of legal positivism that is more interesting than contemporary legal positivism and that it is this version of legal positivism that is worth pursuing.
\end{abstract}

\section{The Road Not Taken}

When H.L.A. Hart defended legal positivism in his famous Holmes Lecture he sought to do so "as part of the history of an idea." In his hands this idea grew out of two philosophical traditions: one is utilitarianism while the other is, as he put it, the "important truth that a purely analytical study of legal concepts, a study of the meaning of the distinctive vocabulary of the law, was as vital to our understanding of the nature of law as historical or sociological studies." ${ }^{2}$ Together these two ideas led to one "simple but vital distinction" of "law as it is from law as it ought to be."

It is not hard to see that Hart's juxtaposition of these two ideas is problematic: Bentham, to whom Hart ascribes these two ideas, conceived of his utilitarianism as part of an attempt to ground the domain of morals and politics on the same foundations and conducted with the same rigor as the natural sciences. His empiricism implied that the principles of morals and legislation

*Assistant Professor, Osgoode Hall Law School. An earlier version of this essay was presented at the annual conference of the Australian Society of Legal Philosophy in Brisbane in July 20 I I. I thank participants there for their questions and comments.

${ }^{1}$ See H.L.A. Hart, Positivism and the Separation of Law and Morals, 7 I HARV. L. ReV. 593,594 (I 958 ).

${ }^{2} I d$. at $60 \mathrm{I}$.

${ }^{3} \mathrm{Id}$. at 594 . 
had to be based on observation, not conceptual or linguistic analysis. It is true that Bentham dedicated many pages to the analysis of language, but all this work was dedicated to exposing the extent to which language obscured reality. Legal language in particular came under relentless attack, because it was riddled with so many fictions, ambiguities, and mysteries. As such it stood in the way of a clear perception of reality, and ultimately in the way of betterment of the human condition. As Bentham caustically put it "[a] large portion of the body of the Law was, by the bigotry or the artifice of Lawyers, locked up in an illegible character, and in a foreign tongue." ${ }^{\prime 4}$ For him, the only path for true understanding of the law came not from attending to the thick foliage of legal discourse but rather by cutting through it. ${ }^{5}$

Once we see that utilitarianism and linguistic analysis are not natural bedfellows we can turn Hart's claim on its head: there are two distinct ways of defending and understanding legal positivism, one is conceptual, the other normative, and they are not easily joined. In Hart's case it did not take long before he abandoned the link between utilitarianism and legal positivism. Perhaps he no longer thought it necessary to draw such a link when not facing an audience he suspected would not be sympathetic to conceptual inquiry; ${ }^{6}$ or perhaps Hart simply came to see that the two ideas could not be so easily joined. ${ }^{7}$ Be that as it may, in The Concept of Law, published only four years after delivering the lecture, legal positivism's utilitarian connection was largely gone. Legal positivism was still presented as a simple idea that (unlike natural law) did not require taking on "much metaphysics, which few could now accept," ${ }^{8}$ but it was now much more

${ }^{4}$ See Jeremy Bentham, A Fragment on Government 2 i n.r (i 988 ) (1776). The fictional nature of legal language was a major theme in Bentham's work, which, he often said, was preserved by lawyers for selfserving reasons. See Philip Schofield, Utility and Democracy: The Political Thought of Jeremy BENTHAM I I I-3 I (2007); GERALD J. POSTEMA, BENTHAM AND THE COMMON LAW TRADITION 266-67, 27 I78 ( 1986$)$.

${ }^{5} \mathrm{I}$ am less concerned in this essay with the other figure Hart ascribes these views, John Austin. Austin's interests were more different than Bentham's than is usually appreciated, and was more interested in clear language. But it is worth noting that for all his pedantry over law "properly so called," Austin did not see himself as concerned with elucidating prevalent linguistic usage and he rejected it when it did not fit into his scheme. See John Austin, The Province of JurisprudenCe Determined 26-27 (Wilfrid E. Rumble ed., i 995).

${ }^{6}$ On Hart's comments on the difference between his approach and that of the Harvard professors and his worries about the reception of his lecture see NiCOLA LACEY, A LiFE OF H.L.A. HART: THE NiGHTMARE AND THE NOBLE DREAM I 95-96 (2004).

7 See his somewhat different characterization of Bentham's enterprise in H.L.A. HART, ESSAYS ON BENTHAM: STUDieS IN JURISPRUDENCE AND POLITICAL THEORY 2 I-39 (I 982 ); $c f$. P.S. ATIYAH \& ROBERT S.

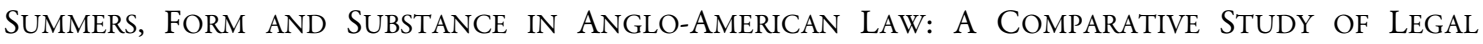
REASONING, LEGAL THEORY, AND LEGAL INSTITUTIONS 256 ( 1987 ).

${ }^{8}$ H.L.A. HART, THE CONCEPT OF LAW i 88 (2d ed., I 994$)$. 
the result of conceptual analysis and armchair sociology ${ }^{9}$ than the conclusion of any ethical or metaethical inquiry. As late as in the postscript to The Concept of Law Hart wrote: "I still think legal theory should avoid commitment to controversial philosophical theories of the general status of moral judgments and should leave open ... the general question of whether they have ... 'objective standing." ${ }^{10}$ Knowing Hart's personal doubts about this very question, there can be little doubt that part of the attraction that the conceptual version of legal positivism held for him was exactly the fact that unlike other jurisprudential theories he thought that legal positivism did not force him to take a stand on questions about which he was personally conflicted.

It is probably due to the influence of The Concept of Law most defenses of legal positivism in the last fifty years adopted this conceptualist approach. That none of the other prominent legal positivists of the twentieth century was a utilitarian (and, for that matter, that utilitarianism was not a very popular view among moral and political philosophers) may have contributed to a relative lack of interest in pursuing the question of possible links between positivism and utilitarianism. From here it was but a small step to the startling claim made by John Gardner, that Bentham's preference for legislation over the common law-a view that was closely tied to his utilitarianism-is "totally independent of his legal positivism." ${ }^{11}$ Legal positivism was thus stripped by most of its contemporary proponents of the particular historical context in which it appeared, of its links to the Enlightenment, of the many ways in which its (alleged) earlier proponents tied it to their political thought, and turned into a proposition. It was defended as a conceptual truth of "general" jurisprudence, the result of nothing more than careful attention to the "study of the meaning of the distinctive vocabulary of the law."

But if this proposition were to count as a philosophical thesis, not merely an incontestable observational truism, there was a need for a contender. And a contender was duly found; or rather, invented and called "natural law." Now of course, the idea of natural law has provenance going back all the way to earliest recorded Western philosophy, but this, historical, natural law is, as Peter Gay put it "infinitely complex; to draw a map of its growth, its multiple ingredients, its changing modes and varied influence, would be like drawing a map of the Nile Delta." ${ }^{12}$ In this

\footnotetext{
${ }^{9}$ How these two seemingly different projects connect in Hart is explained in Dan Priel, Jurisprudence between Science and the Humanities, 3 WASH. U. JURISPRUDENCE REV. (forthcoming 2012), available at http://ssrn.com/abstract $=1566858$.

${ }^{10}$ HART, supra note 8, at 253-54.

${ }^{11}$ John Gardner, Legal Positivism: 51/2 Myths, 46 AM. J.JURIS. I 99, 2 I 3 (2001).

${ }^{12}$ Peter Gay, The Party of Humanity: Essays in the French Enlightenment i 99 (1954). For detailed surveys see J.B. SCHNEEWIND, THE INVENTION OF AUTONOMY: A History OF MODERN MORAL Philosophy 17-i66 (1998); KNUd HaAkonssen, Natural Law and Moral Philosophy: From
} 
vast river one finds discussions on the foundations of political authority, the limits of political obligation, the origins of property rights and the justification of contractual obligations, along with much else. Little of this was acknowledged in the work of Hart or his followers. In their work all this was ignored and an issue that was, at best, a marginal concern in the work of some natural law theorists, has been turned into its defining characteristic. In this way a broad-ranging family of theories has been bastardized into a proposition to match the proposition that is legal positivism. In its simplest form natural law became the proposition that unjust law is not law. ${ }^{13}$

There was one difficulty with this approach: those who actually called themselves "natural lawyers," those who saw their work as following in the footsteps of earlier natural lawyers, dissociated themselves from this proposition. They saw no difficulty with accepting the claim that there were immoral or unjust laws. ${ }^{14}$ In response, legal positivists have drawn a distinction between "[ $\mathrm{t}$ ]raditional Natural Law ... [which] insist $[\mathrm{s}]$ that a putative norm cannot become legally valid unless it passes a certain threshold of morality"15 and "contemporary Natural Law," which accepts this idea. ${ }^{16}$ This, however, hardly helped as contemporary natural lawyers questioned whether, properly understood, there was ever any of the notable natural lawyers who

Grotius to The SCOTTish Enlightenment (i 996); Brian Tierney, The IDEA Of Natural Rights: STUDIES ON NATURAL RigHTS, NATURAL LAW AND CHURCH LAW I I 50 - I 625 ( I 997 ).

${ }^{13}$ HART, supra note 8, at 8. Admittedly, later in the book Hart considers a few other ideas associated with natural law, but these ideas were still relatively detached from the work of actual natural lawyers.

${ }^{14}$ Most famously John Finnis, NATURAL Law AND NATURAL RigHTS 363-66 (2d ed. 20 i I). In different ways the claim has been made by others of a broadly natural law view. See, e.g., LON L. FULLER, THE MORALITY OF LAW I 53 (rev. ed. I 969); RONALD DWORKIN, TAKING RIGHTS SERIOUSLY 89 (rev. ed. I 978). More recently it has been suggested (by a legal positivist) that the difference between natural law and legal positivism is that the former is only interested in the central case of moral law at the expense of marginal cases and the non-moral aspects of law, whereas legal positivism takes a broader interest in both. See John Gardner, Nearly Natural Law, 52 AM. J. JURIS. I, I 8 (2007). This, however, is not how natural lawyers (or at least some of them) perceive of their enterprise. See, e.g., John Finnis, Law and What I Truly Should Decide, 48 AM. J. JURIS. I07, I I I-I 4 (2003); see also MARK C. MURPHY, NATURAL LAW IN JURISPRUDENCE AND POLITICS 8- 10 (2006).

${ }^{15}$ Andrei Marmor, The Rule of Law and Its Limits, 23 LAW \& PHIL. I, 42 (2004).

${ }^{16} \mathrm{Id}$. at 42 n.66. In fact, the historical dividing line posited by Marmor is mistaken as there are "contemporary" natural lawyers who do claim that unjust law is not law. See, e.g., MiCHAEL S. MOORE, Educating Oneself in Public: CRitical Essays in Jurisprudence 303-04 (2000); Philip Soper, In Defense of Classical Natural Law in Legal Theory: Why Unjust Law is No Law at All, 20 CAN. J.L. \& JURISPRUDENCE 20I (2007); Jonathan Crowe, Reviving the Strong Natural Law Thesis (unpublished manuscript, on file with Author). The picture among natural lawyers, whether "traditional" or "contemporary," is thus more complex than Marmor envisages it and cannot be demarcated along chronological lines. My argument below, however, seeks to identify what unites all (or most) natural lawyers and what separates all (or most) of them from contemporary legal positivists. 
adopted this "traditional" view. This raised a serious question for legal positivists: if the point of legal positivism, if its "insight" as Andrei Marmor called it, ${ }^{17}$ was familiar to medieval natural lawyers, what was the novelty in legal positivism, what was its first proponents' point? And regardless of how this historical question is resolved, this view raises the difficult question of explaining what it is that stands between legal positivism and natural law today. If contemporary natural lawyers agree that unjust law is law, it seems to follow that what is still treated as the most foundational debate in jurisprudence-the one that opens virtually all the textbooks-is one on which there is no argument at all. ${ }^{18}$

In this essay I want to address these questions. I suggest we do so by looking back at the road not taken, the one that links legal positivism to utilitarianism. My claim, however, will not be that legal positivism was a utilitarian position per se, but rather that it was what might be called a metaphysically deep doctrine that was grounded in the very same ideas that led Bentham to his utilitarianism. I will argue that unlike contemporary legal positivism that conceives of itself and the domain of jurisprudence in highly restricted terms, the philosophers now considered its founders saw theorizing about law, just like theorizing about morals, as part of theorizing about nature, and about human nature in particular. Where they differed from natural lawyers was, first and foremost, in their views on these matters.

I have two major aims in this essay. I hope, first, to set the historical record straight, so I offer an account of Hobbes's and Bentham's work that seeks to identify what it was that they believed and to put their views on law in the proper context of their thought. The primary aim of this essay, however, is not historical. My main aim is to contribute to contemporary jurisprudential debates and to suggest that the largely neglected approach of earlier positivists is superior to the view held by most contemporary legal positivists. The two aims are not necessarily congruent. There is an obvious sense in which talk of Hobbes or Bentham as legal positivists is a historical anachronism. The debate between legal positivism and natural law, in the form one finds in contemporary jurisprudence textbooks, is a twentieth century debate that cannot found in jurisprudential debates of past centuries. It is not just that the term "positivist" is not found in the work of Hobbes, Bentham, or even Austin. It is that the debate as it is understood today was not one that

\footnotetext{
${ }^{17}$ Marmor, supra note I 5 , at 42.

${ }^{18}$ Hence the many works that struggle mightily to find some kind of difference between legal positivism and natural law, or calling us to reject this dichotomy. See, for example, id.; Gardner, supra note i I, at 226-27; Gardner, supra note I4, at I 8, 22-23; Brian Bix, On the Dividing Line Between Natural Law Theory and Legal Positivism, 75 NOTRE DAme L. ReV. 1613, I621-23 (2000) (focusing on methodological differences); J.S. Russell, Trial by Slogan: Natural Law and Lex Inuistia Non Est Lex, I9 LAW \& PHIL. 433 (2000); NeIL MACCORMICK, INSTITUTIONS OF LAW: AN ESSAY IN LEGAL THEORY 278-79 (2007); MURPHY, supra note I 4 , at 22-24; DAVID LYONS, ETHICS AND THE RULE OF LAW ios (1984).
} 
they were engaged in. The contemporary debate, at least as understood by contemporary legal positivists, is focused on legal validity, but this concept did not play nearly as important a role in classical legal positivists' work.

There is therefore danger in the attempt to match contemporary categories to the ideas of theorists who worked against a very different intellectual framework, and in an important respect, therefore, it is pointless, and potentially misleading, to debate whether Hobbes or Bentham were "really" legal positivists or natural lawyers. ${ }^{19}$ The more meaningful question is: To what extent is it useful for us to call Hobbes and Bentham "legal positivists"? My answer to this question consists of three interrelated points. The first is that we draw an explicit link between their ideas and the view that (some time later) would come to be known as "positivism," roughly the view that the methods of the "human sciences" are essentially the same as those of the natural sciences. The second point is that the classical legal positivists' decisive break with natural law ideas prevalent in their day is to be found exactly here, in their views about metaphysics or human nature. The third point is to demonstrate how this aspect of their work has been, in my view regrettably, abandoned by contemporary legal positivists. Though all three points are closely related, in this essay I will say relatively little about the first point here, as I discussed it greater detail elsewhere. ${ }^{20}$

\section{Two Versions of Legal Positivism}

The idea that putative laws can be immoral and still remain (in a certain sense) "valid" did not need the genius of Hobbes or Bentham to be discovered. It was always known, because it is a trivial observation. Aristotle, for example, distinguished between the "legally just" and the "equitable," which is "a correction of legal justice."21 Even more clearly Cicero, by contemporary classifications natural lawyer par excellence, ${ }^{22}$ had no difficulty in distinguishing between "legally binding conditions or how to answer this and that question for our clients" - what legal positivists would now call valid legal norms - and the broader inquiry, in which "we have to encompass the entire issue of universal justice and law; what we call civil law will be confined to a small, narrow,

\footnotetext{
${ }^{19}$ Cf. Quentin Skinner, Meaning and Understanding in the History of Ideas, 8 HIST. \& THEORY 3 ( 969 ).

${ }^{20}$ Priel, supra note 9.

${ }^{21}$ ARistotle, Nicomachean ETHiCs 98-99 (Oxford University Press, W.D. Ross trans. \& Lesley Brown ed., 2009) (V.ro).

22 "[L] aw in the proper sense [or as we might say today 'properly so called'] is right reason in harmony with nature. It is spread through the whole human community, unchanging and eternal. ... This law cannot be countermanded, nor can it be in any way amended, nor can it be totally rescinded. We cannot be exempted from this law by any decree of the Senate or the people...." Cicero, The Republic, in THE REPUBLIC AND THE LAWS I, 68-69 (Oxford University Press, Niall Rudd trans., I 998) (III.33).
} 
corner of it." ${ }^{23} \mathrm{He}$ had no difficulty in understanding that "as our whole discourse has to do with ordinary ways of thinking, we shall sometimes have to use ordinary language, applying the word 'law' to that which lays down in writing what it wishes to enjoin or forbid. For that's what the man in the street calls law." ${ }^{24}$ Aquinas too clearly recognized the possibility of iniquitous or immoral laws: "Human laws often bring defamation and injury to human beings." ${ }^{25}$ Not only that, he even provided a typology of the different ways in which they may be unjust. ${ }^{26}$ These thinkers were also fully aware of the, utterly obvious, practical implications of disobeying unjust laws. Even Augustine, who is usually given credit for first use of the slogan "unjust law is not law," should be read in context. The words appearing in the sentence just preceding these famous words consider the following hypothetical: "the law bids a soldier to kill the enemy, and if he holds back from the bloodshed he pays the penalties from his commander." ${ }^{27}$ The practical implications of failure to comply with an unjust law, exactly the consideration John Austin relied upon in his famous refutation of natural law, ${ }^{28}$ were not in question. But those implications were not seen as relevant for answering the question whether unjust edicts could be laws.

What then was the novelty of the earliest philosophers we now call legal positivists? My argument will be that Hobbes and Bentham offered a distinct approach to legal theory that is very different from the work of contemporary legal positivists and in a way is much closer in spirit to the approach to jurisprudence found among natural lawyers. The hallmark of contemporary legal positivism is its internality: it seeks to offer a theory of law from within legal practice, and as such

\footnotetext{
${ }^{23}$ Cicero, The Laws, in THE RePUBLIC AND THE LAWS, supra note 22, at 95, 102-03 (I.17).

${ }^{24}$ Id. at 103 (I.19).

${ }^{25}$ AQuinas, On Law, MORAlity, AND POlitics 64 (Hackett, Richard J. Regan trans., 2d ed. 2002) (S.T. I-II Q.94 Art.4).

${ }^{26}$ Id. at 65 (S.T. I-II Q.94 Art.4). In Aquinas's discussion of the conditions under which laws may be changed, he says that one such case is when "the existing law is clearly unjust." Id. At 72 (S.T. I-II Q. 97 Art. 2). There would be no for such change, if "clearly unjust" laws were not laws. For more on Aquinas's views on unjust laws see John Finnis, The Truth in Legal Positivism, in THE AuTONOMY OF LAW: EsSAYS ON LEGAL PositivisM 195, 20I-03 (Robert P. George ed., I 996). For a more general discussion of the role and different senses of positive law in Aquinas's work see James Bernard Murphy, The Philosophy of Positive Law: FOUNDATIONS OF JURISPRUDENCE 48-I I 6 (2005).

${ }^{27}$ Augustine, On the Free Choice of the Will, On Grace and Free Choice and Other WRITINGS Io (Peter King ed. \& trans., 2010) (\$ I.5.I I.33).

28 "Suppose an act innocuous, or positively beneficial, be prohibited by the sovereign under the penalty of death; if I commit this act, I shall be tried and condemned, and if I object to the sentence, that it is contrary to the law of God, who has commanded that human lawgivers shall not prohibit acts which have no evil consequences, the Court of Justice will demonstrate the inconclusiveness of my reasoning by hanging me up." AUSTIN, supra note 4, at 158.
} 
one that is built around the way law is understood by lawyers. Such an enterprise is almost by definition metaphysically shallow and aims to be politically neutral. The central concept in the effort to explain the "nature" of law, legal validity, directs the inquiry to identifying what members of the legal community consider to be law. Revealingly, in an interview Hart gave late in his life he said about of his main work in jurisprudence that it was "written for lawyers and primarily had them in mind." ${ }^{29}$ (From this point of view the possibility of "valid" immoral or unjust laws is, to put it mildly, not particularly surprising and does not reflect any deep philosophical insight; it is a trivial empirical observation.) But in this sense legal positivism simply does not engage natural law theory: as we have seen natural lawyers were aware of this observation and thought it worthwhile to offer their theory of law as a challenge to the lawyers' perspective. Within this approach the philosophy of law arrives at law from outside. By this I do not mean that it adopts "the external point of view" to legal obligation: this is the mistaken contemporary legal positivist take on the classical positivist view. Rather, what I mean is that the classical philosophical work on law seeks an account of law as part of a broader picture of nature and human nature.

As I will argue this is characteristic not only of the work of those theorists we now call natural lawyers, but also of those now considered founders of legal positivism. A central aim of this essay is to show the significance of this divide in the characterization of legal theory. I begin by describing, in very brief terms, some of the central tenets of the work of Hobbes and Bentham that demonstrate my claim. For ease of exposition I will reverse chronological order and discuss Bentham first.

\section{(a) Jeremy Bentham}

With Bentham a good place to start is morality, not law. Bentham had little patience for most moral discourse, to which he refers with characteristic acidity: thus, for instance, he described the "summum bonum" as "consummate nonsense." 30 Famously, this attitude extended to talk of natural law and natural rights. His basic view on natural rights is found in crisp form in the most famous sentence he ever wrote: "Natural rights is simple nonsense: natural and imprescriptible rights, rhetorical nonsense, nonsense upon stilts" ${ }^{31}$ As rights were the products of human law, talk

\footnotetext{
${ }^{29}$ Hart Interviewed: H.L.A. Hart in Conversation with David Sugarman, 32 J.L. \& SOC'Y 267, 291 (2005); see also JOSEPH RAZ, THE AUTHORITY OF LAW: ESSAYS ON LAW AND MORALITY 44 (2d ed. 2009).

${ }^{30}$ Jeremy Bentham, DeONTOlogy 134 (Amnon Goldworth ed., I983) (\$ I.4). Hobbes held the same view: see Thomas HobBes, Leviathan 70 (Cambridge University Press, Richard Tuck ed., rev. student ed. 1996) (ch. I I) [hereinafter HOBBES, LEVIATHAN].

${ }^{31}$ Jeremy Bentham, Nonsense Upon Stilts, in Rights, RePRESENTATION, AND REFORM: NONSENSE UPON STILTS AND OTHER WritingS ON THE FreNCH REVOLUTION 31 7, 330 (Philip Schofield et al. eds., 2002).
} 
of natural law was akin to talk of "cold heat," "dry moisture," or "resplendent darkness." ${ }^{\text {"2 Natural }}$ law was described in similar terms: in the course of his critique of Blackstone Bentham called it a "phantom" and a "formidable non-entity." 33 Such fictional concepts as the law of nature or natural justice were not just confusing but dangerous as they "serv[ed] as cloak, and pretence, and aliment to despotism." 34

Nonetheless, Bentham did not think that there was no right and wrong in human affairs. (Notice that this very is different from the views of some contemporary legal positivists who were drawn to legal positivism exactly because they thought there was no right answer to such questions.) The crucial point for Bentham is that questions of morals have been discussed in the wrong way: "every political and moral question ought to be[ put] upon the issue of fact; and [thus] mankind [would be] directed into the only true track of investigation which can afford instruction or hope of rational argument, the track of experiment and observation." ${ }^{35}$ And Bentham believed he identified the relevant facts, which he presented most famously in the opening sentence of the Introduction to the Principles of Morals and Legislation: "Nature has placed mankind under the governance of two sovereign masters, pain and pleasure. It is for them alone to point out what we ought to do, as well as to determine what we shall do." 36 This, for him, was a matter of fact, a generalization based on observation. It was not meant to be an "internal" description or reinterpretation of people's attitudes, for obviously it did not reflect folk morality. It was considered a discovery meant to rid us of much of the nonsense and fiction that bedevilled moral discourse. It was meant to be a scientific ("external") discovery, one that in turn was grounded in his materialist metaphysical worldview. It is this perspective which led him to dismiss so much of moral, political, and legal discourse as fiction. ${ }^{37}$

${ }^{32}$ All these come from Jeremy Bentham, Supply without Burthen, in I JEREMY BENTHAM, ECONOMIC WRITINGS 283,335 (W. Stark ed., I952).

${ }^{33}$ JeREMY BENTHAM, A COMMENT ON THE COMMENTARIES AND A FRAGMENT ON GOVERNMENT 17, 20 (J.H. Burns \& H.L.A. Hart, eds., I977).

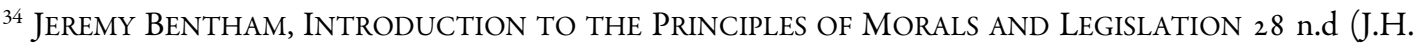
Burns \& H.L.A. Hart eds., I 996) (\$2.14).

${ }^{35}$ Jeremy Bentham, Observations on the Draughts of Declarations-of-Rights Presented to the Committee of the Constitution of the National Assembly of France, in RiGHTS, REPRESENTATION AND REFORM, supra note 3 I, I 77 at 189 .

${ }^{36}$ BENTHAM, supra note 34 at I I ( $\$$ I.I).

${ }^{37}$ See generally Ross HarRison, BENTHAM I 8-33 (1983); JAMES STEINTRAGER, BENTHAM I-27 ( 1977 ). 
Not surprisingly, Bentham held a very similar view of law: "Physical sensibility [is] the ground of law-proposition the most obvious and incontestible $[$ sic $] . " 38$ To understand law one must start not from within legal practice, but from an account of what exists. In his view, for a wellfunctioning legal system one had to first have clear perception of what existed in order to fix (in both senses of the word "fix") legal language accordingly. ${ }^{39}$ It should therefore not come as a surprise that among Bentham's unpublished manuscripts there is one entitled "The Metaphysics of Jurisprudence." ${ }^{40}$ What should be clear from all this is that Bentham's problem with natural law was not that natural lawyers tried to build legal theory of metaphysical foundations, but that the foundations natural lawyers posited were false. The foundations they posited did not exist, just like cold heat did not exist.

These views are clearly very different from what one finds in the work of most contemporary legal positivists, but they are also different from some revisionist interpretations of Bentham's work that suggested that Bentham's views in jurisprudence were motivated by his utilitarianism, and not by conceptual analysis. ${ }^{41}$ There can be no doubt that Bentham's views on law were part of his broader utilitarian outlook. Bentham clearly believed that laws were required for attaining some happiness and avoiding some pain ${ }^{42}$ (which shows, by the way, that for him there was a necessary connection between law and morality: law was a necessary means for attaining moral ends).

I suspect that contemporary legal positivists would respond that whatever Bentham's motivations for his views on law had been, what matters (as far as his legal positivism is concerned) is that Bentham accepted the conceptual claim of the separability of law as it is from law as it ought to be. This, however, is to simply misunderstand what Bentham was concerned with. Bentham,

38 Bentham manuscripts, University College London, Box 69, p. io, quoted in DOUGLAS G. LONG, BENTHAM ON LIBERTY: JEREMY BENTHAM'S IDEA OF LIBERTY IN RELATION TO HIS UTILITARIANISM I 7 ( 1977 ).

39 See Jeremy Bentham, Of the Limits of the Penal Branch of Jurisprudence 286-87 (Philip Schofield ed., 2010).

${ }^{40}$ Bentham manuscripts, University College London, Box 69, p. 2 I 4, quoted in STEINTRAGER, supra note 37 , at 23 .

${ }^{41}$ See e.g,, Postema, supra note _, at 328-36; Philip Schofield, Jeremy Bentham and H.L.A. Hart's 'Utilitarian Tradition in Jurisprudence', I JURISPRUDENCE 147 (2010).

42 "The business of government is to promote the happiness of the society, by punishing and rewarding." BENTHAM, supra note 34 , at 74 ( $\$ 7.1$ ); see also id. at 282 ( $\$$ I 7.2), and the material quoted in J.R. Dinwiddy, Bentham on Private Ethics and the Principle of Utility, in RADICALISM AND REFORM IN BRITAIN, I $780-1850$ 3 I 5, 329 (1992). For further discussion on the role Bentham gave to legislation and government in the pursuit of happiness see L.J. Hume, Bentham AND BUREAUCRACY 93-96 (198 I); L.J. Hume, Jeremy Bentham and the Nineteenth Century Revolution in Government, I 0 HIST. J. 36 I (1967). 
like natural lawyers but unlike contemporary legal positivists, comes to his views about law from an underlying metaphysical worldview, not from observing at the attitudes of participants in legal practice or from careful analysis of the concepts they use. This is why Bentham, despite famously denying the existence of natural law, could write without contradiction that natural law should be better understood as "conformity of the thing in question to the proper standard, whatever that may be," to which he added his own gloss: "On most occasions ... it will be better to say utility: utility is clearer, as referring more explicitly to pain and pleasure." ${ }^{43}$ To suggest that all this is separate from his views on law is simply to ignore almost everything Bentham wrote and ascribe to him a view he never defended.

\section{(b) Thomas Hobbes}

Hobbes is a more complex case, one that at first sight looks very different. Hobbes's writings are replete with references to both the laws of nature and the right of nature, and they are central ingredients to his contractarian argument about the move from the state of nature to civil society. (Bentham, by contrast, dismissed contract arguments as grounded in fiction.) It thus seems plainly false to suggest that Hobbes denied the existence of natural rights or natural law, and it seems that in his account natural laws play a more "active" role than mere standards by which positive law is to be assessed; there is also no doubt that in various important respects Hobbes and Bentham ideas are very different. ${ }^{44}$ And yet, in many respects Hobbes's interpretation of natural law consisted in a radical departure from earlier ideas. He had no patience for the ideas of the "Schoolmen," the humanistic scholars who sought to revive the classical (Greek-Roman) natural law tradition; ${ }^{45}$ it is with him, for example, that we find, probably for the first time, the idea of liberty as non-interference, and his rejection of classical, republican, idea of freedom as nondomination. ${ }^{46}$ More fundamentally, and more importantly, for my argument, Hobbes saw his views about natural law as part of a broader grand theory. It is instructive to consider the structure

\footnotetext{
${ }^{43}$ BENTHAM, supra note 34 , at 27 n.d (\$2.1 4).

${ }^{44}$ On the similarities and differences between Hobbes and Bentham see generally James E. Crimmins, Bentham and Hobbes: An Issue of Influence, 63 J. HIST. IDEAS 677 (2002).

${ }^{45}$ HobBes, LeVIATHAN, supra note 30, at 59 (ch. 8), 85 (ch. I 2); cf. John Finnis, Natural Law: The Classical Tradition, in THE OXFORD HANDBOOK OF JURISPRUDENCE AND THE PHILOSOPHY OF LAW (Jules Coleman \& Scott Shapiro, eds., 2002) I, 5-6 [hereinafter OXFORD HANDBOOK] (arguing that contemporary work in the natural law tradition is continuous with the classical tradition of, say, Aquinas and rejects the natural law ideas found in Hobbes). Interestingly, Hobbes adopted these views relatively late in his life. On this shift in Hobbes's approach see QUENTIN SKINNER, REASON AND RHETORIC IN THE PHILOSOPHY OF HOBBES 2 I 5-326 (1 996 ).

${ }^{46}$ Both issues are discussed in QUENTIN SKInNER, HobBeS AND REPUBLICAN LiberTY (2008). Bentham shared this conception of liberty. The significance of this conceptual shift to jurisprudence has not been sufficiently explored.
} 
of he maintain in his most important philosophical works: in both Leviathan and in his earlier works, he maintain a tripartite structure that began with metaphysical questions, proceeded to a discussion of human nature, and concluded in discussion of moral and political theory. This was no mere question of neat organization. Throughout his work he was much influenced by the advances in science of his time and held a strongly materialistic view of nature, which he thought was relevant to all his ideas. ${ }^{47}$ Hobbes considered it one of the greatest strengths of his work to have abandoned the shaky foundations of scholastic moral and political thinking and put in their stead a theory grounded in a correct view of nature. It was only with him, Hobbes thought, that morals and politics became a science.

This is not the place for a detailed of Hobbes's philosophy in its entirety. In what follows I will try instead to demonstrate the importance of these background ideas to his thought on natural and human law. I wish to demonstrate that for all their differences there is at least one important regard Hobbes's novel treatment of natural law justifies separating him from much of the natural law tradition that preceded him and placing him close to Bentham. ${ }^{48}$

It is well known that Hobbes did not think that people could achieve peace on their own and that an authority over them was necessary to prevent life from descending to chaos. Thus, for Hobbes laws were moral imperative, "the procuration of the safety of the people; to which the sovereign is obliged by the Law of Nature" ${ }^{49}$ As he elaborated on this point:

The RIgHT Of NATURE, which writers commonly call Jus Naturale, is the liberty each man hath to use his own power as he will himselfe for the preservation of his own Nature; that is to say, of his own Life; and consequently, of doing anything which, in his own judgement and reason, he shall conceive to be the aptest means thereunto.

By LIBERTY, is understood, according to the proper signification of the word, the absence of external impediments; which impediments may oft take away part of a man's power to do what he would, but cannot hinder him from using the power left him according as his judgement and reason shall dictate to him..$^{50}$

In Hobbes's account natural right is the state of absolute freedom, the ability to do as one wishes in the absence of any laws. It is not a normative concept, but simply a factual statement about

\footnotetext{
${ }^{47}$ For an extended discussion see Priel, supra note 9.

${ }^{48}$ For illuminating discussions of these issues see PEREZ ZagOrin, HobBES AND THE LAw OF NATURE ch.I-2 (2009) [hereinafter ZAGORIN, LAW OF NATURE]; Perez Zagorin, Hobbes as a Theorist of Natural Law, I 7 INTELLECTUAL HIST. REV. 239 (2007). I do not, however, fully agree with his reconciliation of Hobbes's natural law and legal positivism, as in $i d$. at 253.

49 HobBes, Leviathan, supra note 30, at 23 I (ch. 30). He further explains that "by safety here, is not meant a bare Preservation, but also all other Contentments of life...." Id.

${ }^{50} \mathrm{Id}$. at 9 I (ch. I 4$)$
} 
what people can (physically) do in the absence of external restraints. The sole purpose of enacting law is limiting that natural right for the sake of peace. ${ }^{51}$

Hobbes also offered a distinct understanding of natural law. It was novel in two respects: first, according to Hobbes natural law is a precept of reason concerned with survival, and not with good and evil or justice, and second, natural law is not binding in the state of nature (unless commanded by God). Second, despite people's natural dispositions to follow it, he claimed that as an empirical matter it would not be obeyed in the state of nature. Hobbes is clear that "every private man is Judge of Good and Evill actions ... in the condition of meer Nature, where there are no Civill Lawes.... But otherwise, it is manifest, that the measure of Good and Evill actions, is the Civill Law...." 52 Likewise, in the state of nature "nothing can be Unjust." 33

What is the place of natural laws in this story? Humans have a natural disposition for survival, ${ }^{54}$ and the natural laws are "dictates of Reason ... for they are but Conclusions, or Theoremes concerning what conduceth to the conservation and defence of themselves". ${ }^{55}$ As such they "oblige in foro interno" Hobbes explains that "they bind to a desire that they should take place: but in foro externo; that is, to the putting them in act, not alwayes". ${ }^{56}$ So Hobbes uses here the word "oblige" in a special sense, roughly that of a combination of rational precept towards selfpreservation and a desire for their existence. As humans naturally seek their preservation they can recognize these precepts as conducive to that aim (by contrast from the drunk and the insane who

${ }^{51} I d$. at ${ }^{8}{ }_{5}$ (ch. 26) ("the Right of Nature, that is, the naturall Liberty of man, may by the Civill Law be abridged, and restrained; nay, the end of making Lawes, is no other, but such Restraint; without the which there cannot possibly be any Peace.”); see also id. at 200 (ch. 26).

${ }^{52}$ Id. at 223 (ch. 29), also id. at I Io (ch. I 5) ("Good and Evill, are names that signified our appetites, and Aversions, which in different tempers, customes, and doctrines of men, are different").

${ }^{53} I d$. at 90 (ch. I 3 ).

54 "The greatest good for each is his own preservation. For nature is so arranged that all desire good for themselves." Thomas Hobbes, On Man, in MAN AND CiTizen 33, 48 (DE Homine AND DE CIVE) (Hackett, Bernard Gert, ed., Charles T. Wood et al. trans., i 99 I) (\$ i I.6).

${ }^{55}$ HOBBES, LEVIATHAN, supra note 30 , at i i i (ch. i 5 ).

${ }^{56} \mathrm{Id}$. at $\mathrm{I}$ I 0 (ch. I 5). This shows the anachronism in Dyzenhaus's interpretation, for in Hobbes's account there is no question of whether to "resolve[] ... conflict[s] between positive law and natural law in favour of the latter." David Dyzenhaus, Hobbes and the Legitimacy of Law, 20 LAW \& PHIL. 46I, 467 (200I). Likewise Dyzenhaus's claim that Hobbes's natural laws are "not about the psychological state of readiness of mind to obey, but about the obligation that stems from having reasons for obedience," $i d$. at 473, appears to be inconsistent with the tenor of Hobbes's discussion. 
lose this capacity). ${ }^{57}$ This helps us understand in what sense Hobbes can say that the natural laws are "immutable and eternall" and why their opposites- "Injustice, Ingratitudue, Arrogance, Pride, Iniquity, Acception of persons, and the rest" - "can never be lawfull": ${ }^{58}$ They are immutable and eternal because the natural inclination for self-preservation is immutable (itself a finding Hobbes derives from his observation of humans and animals), and one that Hobbes thinks his natural laws invariably help sustain. And when Hobbes says their opposites cannot be made lawful, he means that they cannot be natural laws for a simple reason, that as a matter of fact they are not conducive to self-preservation: "For it can never be that Warre shall preserve life, and Peace destroy it."

The cause of the human predicament lies in conflict between this human desire for selfpreservation and another desire, the pursuit of power. For in addition to seeking their selfpreservation-and to being able to recognize the laws that are instrumentally rational means for this end of self-preservation-humans also have a "generall inclination ... a perpetuall and restlesse desire of Power after power, that ceaseath onely in Death" ${ }^{60}$ In other words "the Lawes of Nature ... without the terror of some Power, to cause them to be observed, are contrary to our Naturall Passions...." ${ }^{61}$ It is for this reason that "notwithstanding the Lawes of Nature ..., if there be no Power erected ... every man will, and may lawfully rely on his own strength and art, for caution against all other men". ${ }^{62}$ For this reason it is misleading to call the natural laws "law": "men use to call by the name of Lawes, but improperly: for they are but Conclusions, or Theoremes ...; whereas Law, properly is the word of him, that by right hath command over others. But yet if we consider the same Theoremes, as delivered in the word of God, that by right commandeth all things; then they are properly called Lawes". ${ }^{63}$

${ }^{57}$ This explains why Hobbes treats drunkenness as a breach of natural law. See THOMAS HOBBES, ON THE CITIZEN 54 (Richard Tuck \& Michael Silverthorne eds., 1997) (\$3.27n).

${ }^{58}$ HOBBES, LEVIATHAN, supra note 30 , at i io (ch. is).

${ }^{59} \mathrm{Id}$.

${ }^{60} I d$. at 70 (ch. I I).

${ }^{61} \mathrm{Id}$. at $\mathrm{I} 17$ (ch. 17).

${ }^{62}$ Id. at I I7-I 8 (ch. I7). There are two possible explanations for the question why the natural laws do not suffice to prevent war of all against all. One is a story about weakness of the will, a conflict between reason and passion. This is the explanation presented in the text. There is an alternative answer that is more thoroughly rationalistic, in which the state of nature is akin to a $n$-person prisoner's dilemma. On this view fully rational behavior can lead to a suboptimal social equilibrium. Both interpretations have their defenders, but for the purposes of my argument, that seeks only to highlight the way Hobbes characterizes natural law and the place it has in his argument, it matters little why natural law will fail. Both versions of the argument are "naturalistic."

${ }^{63} \mathrm{Id}$. at I I I (ch. I 5). Also: the natural laws "are not properly Lawes, but qualities that dispose men to peace, and to obedience." Id. at I 85 (ch. 26). 
These are the bare bones of Hobbes's views on the origins of law. Any attempt to fit his view neatly into the contemporary labels of "legal positivism" and "natural law" faces severe interpretative difficulties. While certain aspects of his view when taken in isolation may be similar to certain aspects of contemporary theories, Hobbes's views are complex (and not entirely free from internal tensions) and the superficial similarities tend to betray more profound differences. As he sought to break away from the work of earlier natural lawyers, it is no surprising that his account looks very different from the work of contemporary natural lawyers who work from within the Aristotelian-Thomist tradition of natural law. There are also significant differences with the work of other contemporary legal theorists who are often classified as natural lawyers of some sort: It is, for example, difficult to classify him as a natural lawyer in the Fullerian sense of insisting on certain procedural requirements as condition of legality, as Hobbes explicitly stated that "no Law can be unjust. The Law is made by the Sovereign Power, and all that is done by such Power, is warranted, and owed by every one of the people; and that which every many will have so, no many can say is unjust." ${ }^{64}$ The differences between his ideas and those of Ronald Dworkin are profound as well, first because Dworkin denies that there is any metaphysical foundation to morals, but also (and more importantly) because Dworkin's conception of morals and freedom is broadly republican, whereas Hobbes had strongly anti-republican views, and offered a naturalistic account of freedom. ${ }^{65}$

${ }^{64}$ Hobbes, Leviathan, supra note 30, at 239 (ch. 30) (emphasis added). Even when the sovereign transgresses against natural law, his transgression is only against God. Id. at I 48 (ch. 2 I). Dyzenhaus tries to turn Hobbes into a precursor of Fuller by highlighting some of the requirements of legality in Hobbes's text. See Dyzenhaus, supra note 53, at 49I; see also ZAGORIN, LAW OF NATURE, supra note 48, at 95. Dyzenhaus's interpretation is implausible because unlike most people who are bound by the natural laws and by the civil laws that have the same content as well, the sovereign, by definition, is not subject to the civil laws. And given that the requirements of legality are natural laws, they are afflicted by the very same problems that Hobbes thinks will lead to the violation of all other natural laws.

${ }^{65}$ For an attempt to argue that we should understand Hobbes as a kind of Dworkinian natural lawyer see Michael Cuffaro, On Thomas Hobbes's Fallible Natural Law Theory, 28 HIST. PHIL. Q. i 75 (20 I I). Cuffaro points out some interesting similarities between Hobbes's views on interpretation of the law of nature and Dworkin's views on principles. See id at I 8 I-83. These, however, do not suffice to establish his interpretation. There are two difficulties with his approach. First, if we wanted to match Hobbes with contemporary views, then Cuffaro's interpretation is consistent with the view that Hobbes was an exclusive legal positivist, a view that in fact fits his interpretation of Hobbes's ideas much better than the inclusive interpretation he considers. Second and more important, Cuffaro ignores the sense in which for Dworkin morality is a communal enterprise that is "constructed" in debate. Put somewhat crudely Dworkin has a republican conception of morality and politics, and Hobbes was as anti-republican as one could get. The fact Cuffaro himself stresses, that for Hobbes interpretation cannot alter natural law, see id. at i 84-85, is anti-Dworkinian, for whom true (correct) morality 
Similarly, while the temptation to classify Hobbes as a legal positivist is understandable after reading passages such as the one quoted in the last paragraph, the similarities between his and contemporary positivists' views are equally problematic. From a contemporary perspective the latter quotation seems to suggest that Hobbes thought that "legal validity" does not depend on legal content, and that makes him sound like a legal positivist. But delve a little deeper and crucial differences appear. Hobbes reached his views on law not from looking at legal practice, but rather by ignoring, or rather challenging, it. His claims about what law, even those that look "positivist," are not conceptual claims, but rather the conclusions of a political argument, ${ }^{66}$ which in turn Hobbes believed was grounded in his views on human nature. ${ }^{67}$

This difference may seem slight, but its significance is profound. The view Hobbes rejects here is the essence of contemporary legal positivism: both methodologically, in the sense that a theory of law does not depend on political theory, and substantively, in the sense that the foundational concept of jurisprudence is validity and that the "rule of recognition" is a purely social, not political concept. To the extent that legal positivism is understood by its proponents as part of the politically neutral inquiry of "analytic jurisprudence," then Hobbes cannot be associated with that endeavor.

\section{The Closing of the Positivist Mind}

\section{(a) From Classical to Contemporary Legal Positivism}

The debate between classical legal positivists and natural lawyers was, at bottom a debate about metaphysics. This is very different from the way the contemporary debate between legal positivism and natural law is usually understood. The contemporary debate is about the sort of connection that exists between natural law and human law. In this version "natural law" is treated as synonymous with morality ${ }^{68}$ (a view that would have been considered as, at best, inaccurate by both Hobbes and Bentham) and legal positivism has been transformed to the claim that (human)

and law (the two for him are not very different) are the product of a "chain novel" process of constant construction. Both the idea of immutable natural laws and of the exclusivity of the sovereign in determining the content of natural law (about which see in particular THOMAS HOBBES, A DiAlOGUE BETWEEN A PHILOSOPHER AND A STUDENT OF THE COMMON LAWS OF ENGLAND 67 (I 97 I ) (I 68 I , written around I 666) [26-27] [hereinafter HOBBES, DiALOGUE].

${ }^{66}$ See Part IV infra for more on this.

${ }^{67}$ See generally Priel, supra note 9.

${ }^{68}$ This is explicit in, for example, Garnder, supra note I 4 , at 22. 
law is separate or distinct from natural law (i.e., from morality). ${ }^{69}$ The opposing view, natural law, has been similarly refashioned as the view that human law has some kind of connection with morality. Much of what has been written in "general jurisprudence" since the publication of The Concept of Law - the debates between positivists and Ronald Dworkin, the debates between legal positivists and Lon Fuller, the proliferation of various strands of legal positivism (especially, "inclusive" and "exclusive" legal positivism) — is based on this contemporary understanding of natural law and legal positivism, one that is largely without a trace in works from earlier periods. ${ }^{70}$

This is a great yet underappreciated shift in the nature of disagreements in legal theory. Recognizing it helps us understand one of the most curious aspects of contemporary debates in jurisprudence. Contemporary natural law theorists often write as though the old debate is going on; hence one finds in their writings the same depth of argument one finds in the work of earlier natural lawyers and in the work of classical legal positivists. Whatever are the differences among them all natural lawyers seek to understand the fundamental philosophical questions of law as part of a broader inquiry, which depends ultimately on one's views on human nature. ${ }^{71}$ By

${ }^{69}$ For this reason it has often been claimed that (contemporary) legal positivism is agnostic on questions of metaethics. See JeREMY WALDRON, LAW AND DiSAGREEMENT i66-67 (1999); HART, supra note 8, at 254; Joseph Raz, Legal Principles and the Limits of Law, in RONALD DWORKIN AND CONTEMPORARY JURISPRUDENCE 73, 85 (Marshall Cohen ed., I 984). Such statements are false, or at least inaccurate, with regard to classical legal positivism.

${ }^{70}$ In recent years there has been a tendency among self-styled legal positivists to accept that there are necessary connections between law and morality. See JOSEPH RAZ, BETWEEN AUTHORITY AND INTERPRETATION: ON THE THEORY OF LAW AND PRACTICAL REASON I 68 (2009); Gardner, supra note I I, at 223; Leslie Green, Positivism and the Inseparability of Law and Morals, 83 N.Y.U. L. REV. I 835 (2008); Jules L. Coleman, Beyond Inclusive Legal Positivism, 22 RATIO JURIS 359, 383 (2009). This, together with the recognition that (most) natural lawyers do not deny that legal norms can be immoral, see text accompanying note I 6 supra, leaves legal theorists scrambling to find something to separate legal positivism and natural law. See note I 8 supra.

${ }^{71}$ There is, more precisely, a debate among contemporary natural lawyers about the proper foundation for natural law theory, and the place of human nature in it. On one side stand those who believe that a theory of practical reason is relatively independent of an account of human nature. Proponents of the second view believe that an account of practical reason must ultimately be based upon a theory of human nature. For a summary of the different views (and a defense of the former) see Robert P. George, Some Recent Criticisms of Natural Law, 55 U. CHI. L. REV. I 37 I, I 372-74, I 378-83, I 407-28 (1988) (reviewing LLOYD L. WEINREB, NATURAL LAW AND Justice (1 987 ) and Russell HitTINGER, A CRITIQUE OF THE NeW NATURAL LAW THEORY (i 987 )). For an outsider to these debates the differences between the views do not seem huge. It is notable that even proponents of the first view insist that a theory of law can be derived only from engagement in substantive concern with normative questions of value, see Finnis, supra note I 4, at I I 5 , and they do not deny the connection between the 
contrast contemporary legal positivism has been transformed into a philosophical standalone, a view that does not depend on any metaphysical worldview; $;^{72}$ and so in order to have a debate with natural law its proponents had to invent an equivalent version of natural law, a kind of similar, standalone non-metaphysical doctrine. In doing so they have been discussing and trying to refute a view that no-one has ever held. The result is the odd (and yet, I trust, familiar) state of contemporary debate in which disputants both struggle to find differences between legal positivism and natural law but at the same time seem to be talking past each other. At the "conceptual" level-whether there can be unjust laws, or whether morality is a condition of legal validity - there may indeed be little to debate and disagreements, if they exist, seem verbal. But this happens only because what does not get discussed, what indeed is assumed by one side to be irrelevant to the debate, is profoundly different. Because one side grounds its argument in metaphysics while the other insists on not having any, there is a lingering feeling that despite seemingly in agreement on everything the two sides could not be further apart.

foundations of practical reason and a theory of human nature, see FINNIS, supra note I4, at 33-34 (accepting that " $t \mathrm{t}]$ he basic forms of good grasped by practical understanding are what is good for human beings with the nature they have" and that "were man's nature different, so would be his duties"' (quoting D.J. O'CONNOR, AQUINAS AND NATURAL LAW I 8 ( 1 967))); George, supra, at I 4 I 5-i 7.

There is no corresponding debate among contemporary legal positivists. Indeed, I suspect most contemporary legal positivists are only dimly aware of this debate among natural lawyers. To the extent that they are aware of it, one judges from their ignoring it that they consider it irrelevant to addressing jurisprudential questions. Even proponents of legal positivism who have sought to tie their theory of law to an account of practical reasoning have largely limited themselves to "conceptual analysis" of the building blocks of practical reason that is required for a theory of law: the "logical features of concepts like value, reason for action or norm and the nature of the rules of inference governing practical reasoning." JOSEPH RAZ, PRACTICAL REASON AND NORMS Io (2d ed. 1990).

${ }^{72} \mathrm{RAZ}$, supra note 70, at 228 ("Metaphysical pictures are, when useful at all, illuminating summaries of central aspects of our practices. They are, in other words, accountable to our practices, rather than our practices being accountable to them."); Hart, supra note I, at 620-2 I (to argue as natural lawyers do regarding unjust law "would seem to raise a whole host of philosophical issues before it can be accepted. ... So when we have the ample resources of plain speech we must not present the moral criticism of institutions as propositions of a disputable philosophy"); HART, supra note 8, at I 92; SCOTT J. SHAPIRO, LEGALITY 44 (20 I I) ("For our purposes ... the[] deep metaphysical questions [about the origins of a legal system] will largely be ignored"); cf. Gardner, supra note I 4, at 22 . 
The following table summarizes my argument so far:

\begin{tabular}{|l|l|l|}
\hline & Metaphysical legal philosophy & $\begin{array}{l}\text { Non-metaphysical legal } \\
\text { philosophy }\end{array}$ \\
\hline $\begin{array}{l}\text { Non-materialist } \\
\text { conception of } \\
\text { nature }\end{array}$ & Natural law & $\begin{array}{l}\text { Contemporary legal } \\
\text { positivism }\end{array}$ \\
\hline $\begin{array}{l}\text { Materialist } \\
\text { conception of } \\
\text { nature }\end{array}$ & Classical legal positivism & Felix Cohen(? $)^{73}$ \\
\hline
\end{tabular}

The table brings out the different ways in which contemporary and classical legal positivism are opposed to natural law, but also the sense in which they are further apart from each other than each is apart from natural law. It also helps us see how one can be both a legal positivist in the classical sense, even a rather extreme one at that, while in another sense a natural lawyer. Indeed, it is as a result of this analysis that we can see why both legal positivists and natural lawyers have been claiming Hobbes and even Bentham as their own, and also why there is no need to decide on this matter one way or the other.

\section{(b) The Invented History of Contemporary Legal Positivism}

The non-metaphysical version of legal positivism is not just the one that dominates contemporary debates with natural lawyers, it is also projected backwards onto the work of classical positivists Hobbes and Bentham resulting in interpretations of their work that leave out almost everything they said. Marmor, as we have seen, offered the standard story on the difference between traditional and contemporary natural lawyers, also provides in capsule form also the typical account of the historical development of legal positivism:

${ }^{73}$ I mention Felix Cohen in this category tentatively and only for completeness's sake as I do not discuss his views beyond this footnote. Felix Cohen was influenced by the work of the logical positivists, who famously rejected all metaphysics. See Felix S. Cohen, Transcendental Nonsense and the Functional Approach, 35 Colum. L. REV. 809,827 (1935) ("The task of modern philosophy is the salvaging of whatever significance attaches to the traditional concepts of metaphysics through the redefinition of these concepts as functions of actual experience"). At the same time Cohen expressed some views we would now associate with legal positivism, see e.g., Felix Cohen, The Ethical Basis of Legal Criticism, 4I YALE L.J. 201, 205 (193 I) ("Law is law, whether it be good or bad, and only upon the admission of this truism can a meaningful discussion of the goodness and badness of law rest"). But basing his views on logical positivism puts him in quite a different category from that of contemporary legal positivists: he may have held that view that all metaphysical discourse, unless empirically redefined, is meaningless. This is quite different from the view that metaphysics is meaningful but irrelevant to legal philosophy. 
Early legal positivists followed Hobbes' insight that the law is, essentially, an instrument of political sovereignty, and they maintained that the basic source of legal validity resides in the facts constituting political sovereignty. Law they thought, is basically a command of the sovereign. Later legal positivists modified this view, maintaining that social conventions, and not the facts about sovereignty, constitute the grounds of law. ${ }^{74}$

While the early and later legal positivists differed on this score they shared what Marmor considers " $[\mathrm{t}]$ he main insight of legal positivism", namely "that the conditions of legal validity are determined by social facts." 75

This passage neatly captures the invented tradition of legal positivism, the one that treats legal validity as the central question of jurisprudence, and then reads this concern into the work of the classical legal positivists. ${ }^{76}$ It is, however, historically and philosophically confused. First, it should be noted that the idea of law as a command did not originate with Hobbes but was familiar long before him. ${ }^{77}$ Beyond this, it is hard to assess Marmor's exegetical claim because he does not provide any reference to Hobbes's work in support his reading, but as far as I know Hobbes did not write anything that could plausibly be interpreted as concerned with the question of legal validity as the term is currently understood. As I tried to demonstrate above in my outline of his view, the motivation, emphasis and focus of his attention have always been on providing an account of legitimate political authority that builds on the more basic building blocks of what the world and mankind are like. It is true that Hobbes did say some things that to the casual reader may look like a discussion of legal validity. In $A$ Dialogue between a Philosopher and a Student of the Common Laws of England, a relatively late work, he wrote:

[Lawyer:] Are not the Canons of the Church part of the Law of England, as also the Imperial Law used in the Admiralty, and the Customs of particular places, and the by-Laws of Corporations, and Courts of Judicature.

[Philosopher:] Why not? for they were all Constituted by the Kings of England; and though the Civil Law used in the Admiralty were at first the Statutes of the Roman Empire, yet because they are in force by no other Authority than that of the King, they are now the Kings Laws, and the Kings Statutes. The same we may say of the Canons; such of them as we have retained, made by the Church of Rome, have been no

${ }^{74}$ Marmor, supra note I 5 , at 4I-42.

${ }^{75} \mathrm{Id}$. at $4 \mathrm{I}$ (emphasis in original).

${ }^{76}$ It also, erroneously in my view, ascribes this concern with validity on contemporary legal philosophers (such as Dworkin) whose writings clearly are not about validity, which in turn is related to the untying of the links between legal and political philosophy. See Dan Priel, The Place of Legitimacy in Legal Theory, 57 MCGILL L.J. (forthcoming 20 I I ).

77 See Gerald J Postema, Law as Command: The Model of Command in Modern Jurisprudence, I I PHIL. ISSUES 470, 47 I-74 (200I). 
Law, nor of any force in England, since the beginning of Queen Elizabeth's Raign, but by Virtue of the Great Seal of England. ${ }^{78}$

This looks like legal validity, even a precursor of Hart's rule of recognition. Crucially, though, for Hobbes the difference between the pre-legal and the legal is not determined by the mere empirical observation of obedience, but rather on the basis of law as a matter of Hobbes's political theory. ${ }^{79}$ The notion of legal validity is one that takes community understanding of what law is as given and tries to give a theoretical account of it; Hobbes, on the other hand, rejected lawyers' understanding of what constituted law: he rejected Coke's views that sought to establish the common law as having authority independent of the sovereign's, ${ }^{80}$ and he was willing to recognize as law certain things that would not have been accepted as such by the legal community. In the Dialogue, after offering his definition of law, the philosopher, Hobbes's alter ego, is challenged by the lawyer that by his definition, "the Kings Proclamation under the Great Seal of England is a Law" to which the philosopher replies "Why not?" entire common law is not really law, ${ }^{82}$ was equally dismissive of the project of accounting for lawyers' attitudes.

Legal validity is a concept that makes sense, if at all, only within the framework of an attempt to report accepted attitudes (typically of lawyers) as to what counts as law. As such it is a concept that is part and parcel and of the contemporary attempt to refashion legal positivism as a nonmetaphysical doctrine. Within this effort legal validity serves as the alternative to the metaphysical foundations on which the theories of classical legal positivists were based. It plays no explanatory role in a metaphysically deep theory.

Putting legal validity to one side a different idea may be worth examining in charting the shift from classical to contemporary legal positivism. In the work of Hobbes and Bentham (and even Austin) the command theory is primarily a view regarding legal authority. In modern parlance we may say that these theorists sought to show how there is no necessary connection between law and

${ }^{78}$ HobBes, DiAlogue, supra note 65, at 62-63 [i 8]; see also HOBBES, LEVIATHAN, supra note 30 , at i 84-85, I $85-86$ (c. 26).

${ }^{79}$ My conclusion here is similar to that of Jeremy Waldron, Legal and Political Philosophy, in OXFORD HANDBOOK, supra note 45, 352 at 366-68, although more than him I think it shows the sense in which what I call classical legal positivism is fundamentally at odds with contemporary legal positivism.

${ }^{80}$ HOBBES, LEVIATHAN, supra note 30 , at I 86-87, I 9 I-94 (c. 26).

${ }^{81}$ HOBBES, DiALOGUE, supra note 65, at 7 I [33]; see also the quote accompanying note 78 above.

82 BENTHAM, supra note 39, at 25-26; BENTHAM, supra note 36, at 8 (Preface), among many other places. To the same effect is his discussion on the extension of "law" to edicts given by a single monarch as sovereign, where he rejected prevalent linguistic usage. See BENTHAM, supra note 39, at 29-32. 
morality with regard to the question of law's normativity. Consistent with their metaphysical views they sought to offer an account of how law creates obligations that does not depend on moral premises. This was the essence of the command theory: obligations according to Hobbes arise "not from their own Nature, (for nothing is more easily broken than a mans word,) but from Feare of some evill consequence upon the rupture". ${ }^{83}$ When Hobbes later defined law as a "Command ... addressed to one formerly obliged to obey [the commander]", ${ }^{44}$ it was part of his view that political obligation does not depend on morals. Even Austin, who in other respects marks the beginning of the transition towards contemporary legal positivism, is, in this regard, not very different: "the party bound by a command is bound by the prospect of an evil." 85

Hart is famous for subjecting the command theory to withering criticism, but he accepted the classical positivist idea that legal obligation is distinct from moral obligation, that legal rights are distinct from moral rights. In his proposed alternative to the command theory-what has come to be known as the "practice theory of norms"-Hart, like the classical legal positivists, sought a nonmoral ("positivist") account of law's normativity. ${ }^{86}$ With this one matter Hart kept a threadbare connection between his views and those of the classical legal positivists. But with him the fundamental concept of legal positivism was no longer normativity but validity; and so after him having a non-moral account of normativity was no longer thought necessary for one's positivist credentials. This led to the next stage in the development of the idea of legal positivism: not, as Hart (like the classical legal positivists) thought, by distinguishing legal obligation from moral obligation, but rather by separating validity from normativity. ${ }^{87}$ Thus, by the end of the process the concept of legal validity has become so central one could be a legal positivist of good standing in spite of having a moral account of law's normativity, for in the most recent version of legal positivism the separation between law and morality was asserted only with regard to legal validity. With this we could say the shift from classical to contemporary legal positivism was complete.

To summarize: the shift from classical to contemporary legal positivism involved not changing views on legal validity, but a reorientation of jurisprudence by placing legal validity at its center. This shift proved such a spectacular success that it required a reinterpretation of classical legal positivists' work in order to present it as though it was concerned with legal validity; at the same time, the sort of questions that they were actually interested in have not only been ignored, but are often nowadays treated as not really belonging to jurisprudence.

\footnotetext{
${ }^{83}$ HOBBES, LeVIATHAN, supra note 30 , at 93 (ch. I 4); see also HOBBES, supra note 57, at 175 ( $\$$ XV.7).

${ }^{84}$ HOBBES, LEVIATHAN, supra note 30 , at 183 (ch. 26).

${ }^{85}$ AUSTIN, supra note 27, at 23.

${ }^{86}$ See HART, supra note 7, at I 44-47, I 58-6 I (1982).

87 See RAZ, supra note 29, at I 58; Gardner, supra note II, at 213. Raz rejected Hart's views on legal obligation in RAZ, supra note I02, at 269-82.
} 


\section{Three Methodological Comments}

I believe there is much to be said in favor of classical legal positivism. Even if ultimately false, it is in my view far superior to contemporary legal positivism. To state just one reason why a legal philosopher might be more interested in it, classical legal positivism is a doctrine to which philosophers may well contribute; contemporary legal positivism, despite its philosophical aspiration is, I think, either an empirical observation or a linguistic stipulation. On either legal philosophers have little to contribute, which is why I judge the dominant conceptual version of legal positivism of the last fifty years to have been a rather spectacular failure. However, a full blown defense of a modern version of classical legal positivism cannot be undertaken here. Instead, I will dedicate this last section of the essay to three questions of method, of how to get to a contemporary version of classical legal positivism. They are particularly important given the centrality of methodological debates to contemporary jurisprudence. I will first consider the question whether the two versions of legal positivism may find common ground in a shared methodology. I will consider and reject a suggestion by Brian Leiter that may be interpreted in this way. The second subsection is, in a way, an application of my argument of the first. Specifically, I consider there what role, if any, should be given to the internal point of view within classical legal positivism. My conclusion on the matter is rather negative: I argue that the internal point of view is tied to contemporary legal positivism; with its demise much of the motivation for adopting the internal point of view no longer holds much sway. The third subsection moves to a somewhat different territory. I consider there the potential challenge that if my arguments about the substantive and methodological differences between the two versions of legal positivism are so significant, it is wrong-indeed, it may be positively misleading - to use the same term for both.

\section{(a) Can Classical and Contemporary Legal Positivism Be Joined by their Method?}

It may be the case that if one is a metaphysical positivist a certain version of legal positivism follows. If this is true, it already somewhat undermines contemporary legal positivists' attempts to draw allegiance with classical legal positivists because the intellectual motivations for classical and contemporary legal positivism are entirely different: contemporary legal positivism seems motivated by their concern for a clear distinction between law and morality and perhaps more generally between law and non-law when observed from the perspective of legal practitioners whereas classical legal positivists are there to explain the foundations of legitimate political authority and the role of law within such structure as they emerge from their particular view of (human) nature.

Perhaps, then, it could be shown that despite these fundamental substantive differences, the two versions of legal positivism could be accommodated in their methodology. I will examine this question by considering an argument advanced by Brian Leiter that, though not directly 
addressing this question, may be understood as suggesting such a possibility. Leiter is a leading proponent of the view that seeks to ground legal positivism on metaphysical grounds broadly similar to those of Hobbes and Bentham. ${ }^{88}$ Leiter seems to think there is a fairly straightforward link between "naturalism"-roughly what I call metaphysical positivism-and contemporary "exclusive" legal positivism; my arguments so far show, I hope, why I think this view is mistaken. ${ }^{89}$ But in some of his writings Leiter suggests a weaker version of naturalism. Adopting something like this view may look like the metaphysically shallow basis that could unite contemporary and classical legal positivists. I think this suggestion will not do either, and in this subsection will try to explain why.

Leiter distinguishes between two distinct versions of naturalism, one a set of methodological theses, which, following him, I will call "M-naturalism," and another a set of substantive theses ("S-naturalism"). Leiter takes it that naturalism is "always first a methodological view to the effect that philosophical theorizing should be continuous with empirical inquiry in the sciences." 0 Within M-naturalism he further distinguishes between "Results Continuity," which is the view that "the claims of philosophical theories be supported by the results of successful sciences," the more modest "Methods Continuity," which "demands only that philosophical theories emulate the 'methods' of inquiry and styles of explanation characteristic of successful sciences." 92 By contrast Leiter defines S-naturalism as "either the (ontological) view that the only things that exist are natural or physical; or the (semantic) view that a suitable philosophical analysis of any concept must show it to be amenable to empirical inquiry." ${ }^{93}$ Leiter argues legal philosophers should adopt M-naturalism. ${ }^{94}$

88 BRIAN LEITER, NATURALIZING JURISPRUDENCE: ESSAYS ON AMERICAN LEGAL REALISM AND NATURALISM IN LEGAL PHILOSOPHY (2007). Surprisingly, Leiter does not seek to reconnect his ideas on legal philosophy, and legal positivism more specifically, to that of Bentham and Hobbes. Even more surprisingly, Leiter is sympathetic to Hart's work.

${ }^{89}$ For an extended discussion see Priel, supra note 9.

${ }^{90}$ LEITER, supra note 88 , at 34 .

${ }^{91} I d$.

${ }^{92} I d$.

${ }^{93} I d$. at 35 n.96.

${ }^{94}$ In some of his writings Leiter seems to at least allow for the possibility of S-naturalism as a possible foundation for jurisprudence. See id. at 39-40, but more recently he rejected it as a possible foundation for jurisprudence and stated that jurisprudence should be limited only to methodological naturalism. See Brian Leiter, Naturalizing Jurisprudence: Three Approaches, in THE FUTURE OF NATURALISM 197, I97-99 (John R. Shook \& Paul Kurtz eds., 2009). 
I think M-Naturalism as distinct from and prior to S-naturalism is either uninteresting or false. Let us begin with methods continuity, the narrowest form of naturalism in Leiter's classification, and see what it amounts to. The idea here seems to be that only what counts as good ways of generating (what we take to be) true scientific propositions should be used in philosophy. Leiter does not elaborate on those methods, but presumably he thinks about the formation of theories based on drawing inferences only if they follow logically from the data or if they are supported by statistically significant evidence. A scientific result is not considered valid until it is replicated, and a putative theory is not considered scientific if it is not testable and refutable.

By these standards, however, virtually all "analytic" philosophers are M-naturalists. Philosophers present theses in which clearly defined premises are meant to lead to conclusions that are thought to follow from them. A philosophical thesis, much like a scientific theory, is refuted by presenting counter-examples to it, which lead either to refinement of the theory or to its abandonment. In other cases a philosophical thesis can be refuted on purely logical grounds, e.g. by showing that its premises are contradictory, that its premises do not entail its alleged conclusion, or that it rests on a logical fallacy. Whenever a philosopher presents an argument she offers it to fellow philosophers for "testing" and "replication" in philosophy departments' seminar rooms. In this respect legal philosophers are no different from the rest of the philosophical crowd: when Hart or Raz argued that sanctions are not a necessary element of a legal system they did it by offering a counterexample of an imaginary case of something that we would think of as a legal system even though it contained no sanctions. If anything, analytic legal philosophy is even more committed to scientific method in this narrow sense that the rest of analytic philosophy as the mainstream view among analytic legal philosophers is that the primary task of jurisprudence is to provide a general account of the "nature" of law by trying to identify its necessary features in a manner not unlike that of a scientist trying to identify the chemical elements that necessarily make up, say, water. ${ }^{95}$

So this is not a very interesting claim. Leiter argues that philosophers can (and should be) also M-naturalists in the sense that their views be supported by the results of science. Again Leiter provides little explanation as to what he means by "supported" but at one point he offers an example: "A philosophical account of morality that explains its nature and function in ways that would be impossible according to evolutionary theory would not, by naturalistic scruples, be an acceptable philosophical theory." ${ }^{\prime 6}$ I cannot see how any philosopher, naturalistic or not, could argue with that. I take it as trivial that philosophers should advance theses that are consistent with

${ }^{95}$ For more on this analogy see Dan Priel, The Scientific Model of Jurisprudence, in NEUTRALITY AND THE PHILOSOPHY OF LAW (forthcoming $20 \mathrm{I} 2$ ), available at http://ssrn.com/abstract $=$ I 5 I 5647.

96 Brian Leiter, Naturalism and Naturalized Jurisprudence, in ANALYZING LAW: ESSAYS IN LEGAL PHILOSOPHY 79, 82 (Brian Bix ed., I 998). 
true scientific theories, simply because their theses should be true. If proposition $P$ contradicts proposition $Q$, and we know that $Q$ is true, then $P$ is necessarily false, and it does not matter whether one proposition is "scientific" and the other "philosophical." So in this sense Mnaturalism is obvious. Indeed, in this respect the focus in Leiter's definition on the natural sciences is possibly too narrow. Philosophical theses cannot be true if they contradict any true facts, including social facts, and given legal philosophy's subject-matter it is much more likely that if it contradicts any true fact, it would be a social fact, not a fact discovered by one of the natural sciences. Whether there are social facts that cannot be reduced to natural facts is, of course, a controversial question, but if we only subscribe to M-naturalism, we cannot assume that all social facts are reducible to natural facts, for that is a controversial substantive thesis. ${ }^{97}$ In this sense the claim of M-naturalism is obvious and no philosopher, naturalistic or otherwise, should deny it.

What is at stake in the question under discussion is the extent to which facts about the world, for example facts about evolutionary theory, are relevant to jurisprudence. The real issue turns on the claim that some arguments could be true or false regardless of what the world turns out to be, and this presumably is where many contemporary legal positivists would situate their arguments. ${ }^{98}$ They can then happily accept the constraints of M-naturalism and maintain that they can go on doing more-or-less what they have been doing all along, because the results of science, whatever they may be, do not affect their inquiries.

Here is where the metaphysical positivism of the classical positivists comes to the fore: it is the claim that the domain of "philosophical" questions about law whose truth does not depend on premises on what the world is like does not exist. This, however, is not a methodological claim but a substantive one. On this view there is no purely "philosophical" argument, because there is no pure "philosophical" domain. Slightly more weakly, it might be argued that no important questions about law belong to that domain. Both claims, however, are firmly committed to a version of $S$-naturalism. These are claims about the metaphysics of social facts, of law, or both. It is, in essence, a combination of the claim that legal positivism must be a metaphysically deep doctrine and that naturalism (metaphysical positivism) provides the most accurate metaphysical account. Contrary to Leiter, then, naturalism is first a substantive view, not a methodological one.

${ }^{97}$ See, e.g., J.A. Fodor, Special Sciences (or: Science as a Working Hypothesis), 28 SYNTHESE 97 (1974); Frank Jackson \& Philip Pettit, In Defence of Explanatory Ecumenism, in Mind, MORALITY, AND EXPLANATION: SELECTED COLlabORATIONS I63 (2004).

${ }^{98}$ For views that (implicitly) adopt exactly this view see, for example, RAZ, supra note 71, at 159-60; SHAPIRO, supra note 72, at 406-07 n.I6; John Gardner, Law's Aims in Law's Empire, in EXPLORING LAw's EMPIRE 207, 208 (Scott Hershovitz ed., 2006). All these authors (and incidentally, all contemporary legal positivists) invoke otherworldly examples in support of their claims about the nature of law. 
Legal philosophers should care about the natural sciences only if the world (nature, human nature) happens to be one way and not another.

Going back to the debates in jurisprudence that have been the subject of this essay, what emerges from this argument is that to the extent that classical legal positivism and contemporary legal positivism are on different sides on the question of naturalism, they cannot be easily accommodated even at the level of methodology. More specifically, the potential for accommodating naturalism with any particular version of contemporary legal positivism seems suspect.

\section{(b) Classical Legal Positivism and the Internal Point of View}

The last section was rather abstract. This section continues with the same theme but does so by considering one specific issue, the "internal point of view." The standard positivist interpretation of the development of legal positivism from Hobbes to Hart locates the error of the classical legal positivists in their adoption of the external point of view in trying to explain the nature of law. The result, according to this story, is the adoption of some version of a command theory of law according to which legal obligation depends only on the threat of sanction. Contemporary legal positivism corrected this error by emphasizing the fact that law is often taken by people to provide them with reasons for actions, a fact that command theories fail to take into account.

My argument above purported to show that it is wrong to locate the tension between classical and contemporary legal positivism here. Nonetheless, in one sense this claim is not entirely mistaken: a direct implication of my argument is that classical legal positivists were not concerned with identifying or describing legal validity. This claim has an interesting corollary in the context of the internal point of view. As Hart put it, the external perspective "may very nearly reproduce the way in which the rules function in the lives of certain members of the group, namely those who reject its rules", but ignores those for whom "the violation of a rule is not merely a basis for the prediction that a hostile reaction will follow but a reason for hostility." 99 Although Hart did not distinguish clearly between them, hart's discussion of the internal point of view contains both a substantive claim about the existence-conditions of law and a methodological claim about the correct way to address the fundamental questions of jurisprudence. The substantive thesis is simply the other side of the view that makes legal validity the fundamental concept of jurisprudence. The methodological thesis addresses the correct way of explaining human action and in particular the claim that the methods of science-exactly the methods on which Hobbes and Bentham tried to base their theories-are incapable of explaining certain forms of human behavior, including the institutions of law.

\footnotetext{
${ }^{99}$ HART, supra note 8, at 90 (first emphasis added).
} 
Why classical legal positivists reject the substantive claim should by now be obvious. Does disentangling the two senses of the internal point of view leave it open for classical legal positivists to accept the methodological internal point of view? There is a view that does exactly that: these days it usually goes by the name "natural law." A staple of most versions of natural law is exactly the rejection of the naturalist methodology of the classical legal positivists. Second, what may have been part of the motivation for the rejection of naturalistic methodology in the days of Hart is no longer a valid consideration. At least in part the motivation for rejecting naturalistic methodology was the view that it cannot give an adequate account of reason-based activity. No doubt some of Hobbes and Bentham's attempts at human psychology look crude by today's standards, because of the state of science of their day. The unavailability of adequate scientific methods for investigating human reasoning may have been true as late as the time Hart wrote The Concept of Law. But this attitude is much less convincing these days when much of cognitive psychology is concerned exactly with explaining reason-based behavior. ${ }^{100}$ In fact, one of the most accepted findings in cognitive psychology is that reports based on introspection by those engaged in normative activity (what legal philosophers call their "self-understanding") are often inaccurate, self-serving, or are after-the-fact rationalizations.

The only way to vindicate looking at those self-understandings in the introspective fashion favored by proponents of the internal point of view is if the attitudes revealed by this methods are themselves are the object of inquiry. Contemporary legal positivism may be understood as an attempt to provide an account of those. But if that is the case, we see once again, albeit via a different route, the difference between the questions that contemporary and classical legal positivists have been interested in.

(c) What's in a Name?

If this is true, if indeed contemporary legal positivism and classical legal positivism are such radically different ideas, does it make sense to speak of both as "legal positivism"? One way of explaining why it might make sense is by linguistically distinguishing two senses of "positivism." Contemporary legal positivists find the label "positivism" apposite because it insists that all law is posited, or laid down. John Gardner asks, for example, "What should a 'legal positivist' believe if not that laws are posited?" 101 Similarly, when Joseph Raz speaks of "positivistic standards" as the

${ }^{100}$ Cf. Dan Priel, Jurisprudence and Psychology, in NEW WAVES IN PHILOSOPHY OF LAW 77 (Maksymilian Del Mar ed., 20 I I).

${ }^{101}$ Gardner, supra note I I, at 200. For a more detailed, but in my view unsuccessful, attempt to defend this view see John Gardner, Some Types of Law, in COMMON LAW THEORY 5 I (Douglas E. Edlin ed., 2008). 
only legal standards what he has in mind are posited standards. ${ }^{102}$ By contrast the classical legal positivists, none of whom ever used the word "positivism" or "positivist," may be thought to be positivists primarily because their views on law derive from a comprehensive methodological/metaphysical picture that could be called positivistic, a particular view about what the world is and a corresponding view about what this implies about the appropriate methods for investigating it. The classical legal positivists are, if you wish, metaphysical positivists who worked out the implications of their positivism to law.

This, however, only makes the difference between the two versions of legal positivism even more profound. Even if we keep these two senses apart as I did here, by carefully distinguishing between the "classical" and the "contemporary," is it not misleading to use a similar term to describe both and to suggest thereby the existence of some kind of link where none exists? In a sense this is merely a terminological question, for as long as we are clear about the differences between what I called classical and contemporary legal positivism, the names do not matter much. But, especially since the term "legal positivism" did not exist in Hobbes or Bentham's days and they never used it to describe their views, would it not be more profitable to stop using the term when talking about their views? Perhaps. It is important for me to stress that I am not here concerned with defending some "canonical" version of legal positivism as the "real" version of legal positivism. Ideas can be demarcated in different ways which may be useful (or "correct") for different purposes. I also do not have any strong attachment to the label "legal positivism" and even less so to the views currently defended under it. Since on certain important issues I believe Hobbes and Bentham had the better view, it might be preferable (at least for someone like me) to try and dissociate such views from those defended by contemporary legal positivists.

There are, however, at least three reasons why, with all the points just made borne in mind, using the term "legal positivism" may be useful for describing the work of Hobbes and Bentham. First, there may be value in keeping the label that highlights the historical path that leads from Hobbes or Bentham to Hart or Raz. It is a meandering route, in which quite often later theorists misunderstood, misapplied, or explicitly changed the ideas of their predecessors. Consequently the juxtaposition of different "legal positivists" at both ends of this historical path can result in some truly odd couples. But to a story in the development of ideas, there may be value in seeing what Austin took from Bentham, what Hart took from Austin, and what Raz took from Hart, and more generally how one theoretical position could, eventually, beget a view that is in some respects diametrically opposed to it. Second, even though the term "positivism" was only coined by Auguste Comte in the middle of the nineteenth century, similar ideas have been around for much

102 JOSEPH RaZ, ETHICS IN THE PUblic DOMAin: ESSAYS ON THE MORALiTy OF LAW AND POLITICS 206 (rev. ed. I 995); see also Hans Kelsen, On the Pure Theory of Law, I ISRAEL L. REV. I, 2 ( I 966) ("In order to be 'positive' a legal norm ... must be 'posited'...."). 
longer. Using the term "legal positivism" to describe some of Hobbes or Bentham's ideas may be useful in highlighting the fact that they were (contrary to most contemporary legal positivists) metaphysical positivists, and in this way to highlight the connections between their ideas and broader changes in the intellectual landscape of Western thought. Finally, and most importantly, there is one doctrine that many (not all) legal positivists, classical and contemporary, share, and that is a non-moral account of law's normativity. As I argued above, it is by looking at this issue that we can see the shift from a focus on normativity to a focus on validity and with it the point at which contemporary legal positivism has finally cut its ties with classical legal positivism. No doubt that story can be told without calling these two views "legal positivism," but the similar term highlights the jurisprudential connections that do exist between these positions.

\section{Conclusion: Towards Classical Legal Positivism}

The successes of the scientific method put enormous pressure on other methods of inquiry. Philosophers in particular may have felt a need to justify their methods when many questions that used to belong to philosophy were subjected to scientific takeover. The response adopted by Hart and some of his contemporaries was to turn philosophy into a subject concerned with questions that science could not possibly touch. (Tellingly, a rather similar move is discernable in religion.) The adoption of the internal point of view was part of the same move. It insulated (or seemed to insulate) legal philosophy from the potential encroachment of science by delineating certain questions, and by implication the domain of legal philosophy, as a separate from that of science. But this "internalist" approach to legal philosophy has proven destructive for the subject. The insistence that legal philosophy is concerned with conceptual questions pursued for their own sake, that concern with the practical significance of jurisprudential debates is "fundamentally antiphilosophical," 103 succeeded to secure the subject from intrusion from without only by killing it from within.

Unfortunately this is now in many circles the dominant view about the proper domain of jurisprudence, so much so that it is sometimes suggested that this is the only way of doing proper,

${ }^{103}$ Gardner, supra note I I, at 203; see also Matthew H. Kramer, Book Review, 58 CAMBRIDGE L.J. 222,223 ( I 999) (contrasting "non-philosophical jurisprudence-a search for a legal theory focused firmly on practical concerns" with "pure philosophical elucidation"). The contrast between these words, coming from prominent contemporary legal positivists, and Bentham's view is striking: "Philosophy is never more worthily occupied, than when affording her assistance to the economy of common life: benefits of which mankind in general are partakers, being thus superadded to whatever gratification is to be reaped from researches purely speculative. It is a vain and false philosophy which conceives its dignity debased by use." Jeremy Bentham, Panopticon; or, the Inspection House, in 4 THE WORKS OF JEREMY BENTHAM 37, I I 7 n.† (John Bowring ed., I 843 ). 
"analytic" legal philosophy. There is, however, a different response to the challenge posed by science, namely embracing it, and it is the one that Hobbes and Bentham adopted. In mentioning them I am not simply appealing to the authority of great dead philosophers. I would like to think that I would have thought this approach worth pursuing even had Hobbes and Bentham not existed. But it is worth demonstrating just how far the contemporary positivist approach is from the ideas of those usually considered, by contemporary legal positivists themselves, as founders of legal positivism.

Ironically, the turn to science could open up the field for what we might call more genuinely "philosophical" questions. Instead of trying to answer the fundamentally sociological question "what is law?," legal philosophers could turn their attention to questions like "given particular physics and metaphysics, what laws can (and cannot) be?," or to the kind of "Kantian" philosophical puzzle, "what makes law (legal obligation, legal authority, legal normativity) possible?," or to a question like "given certain facts about nature (including human nature) what should laws be?" Though such questions will presumably depend on facts about human nature, they are not sociological questions and an answer to them does not depend on people's attitudes on the matter. ${ }^{104}$ This is what I take to have been the essence of classical legal positivism. Had this approach to legal philosophy been taken more seriously the views that go by the name "legal positivism" would have looked quite different from what they actually look like these days, no doubt more interesting, and probably more plausible.

${ }^{104}$ More precisely, they are immune to them to the extent that they are not constitutive of legal practice. See Danny Priel, Jurisprudence and Necessity, 20 CAN. J.L. \& JURISPRUDENCE 173, 93-94 (2007). 